University of South Florida

DIGITAL COMMONS

Digital Commons @ University of

@ UNIVERSITY OF SOUTH FLORIDA

South Florida

School of Information Faculty Publications

School of Information

2008

\title{
The Use of CMC Technologies in Academic Libraries
}

Courtney Crummett

National Institutes of Health

Anna Perrault

University of South Florida, perrault@cas.usf.edu

Follow this and additional works at: https://digitalcommons.usf.edu/si_facpub

Part of the Library and Information Science Commons

\section{Scholar Commons Citation}

Crummett, Courtney and Perrault, Anna, "The Use of CMC Technologies in Academic Libraries" (2008). School of Information Faculty Publications. 40.

https://digitalcommons.usf.edu/si_facpub/40

This Book Chapter is brought to you for free and open access by the School of Information at Digital Commons @ University of South Florida. It has been accepted for inclusion in School of Information Faculty Publications by an authorized administrator of Digital Commons @ University of South Florida. For more information, please contact digitalcommons@usf.edu. 


\section{Handbook of Research on Computer Mediated Communication}

Sigrid Kelsey

Louisiana State University

Kirk St.Amant

East Carolina University, USA

Volume II

Information Science REFERENCE 


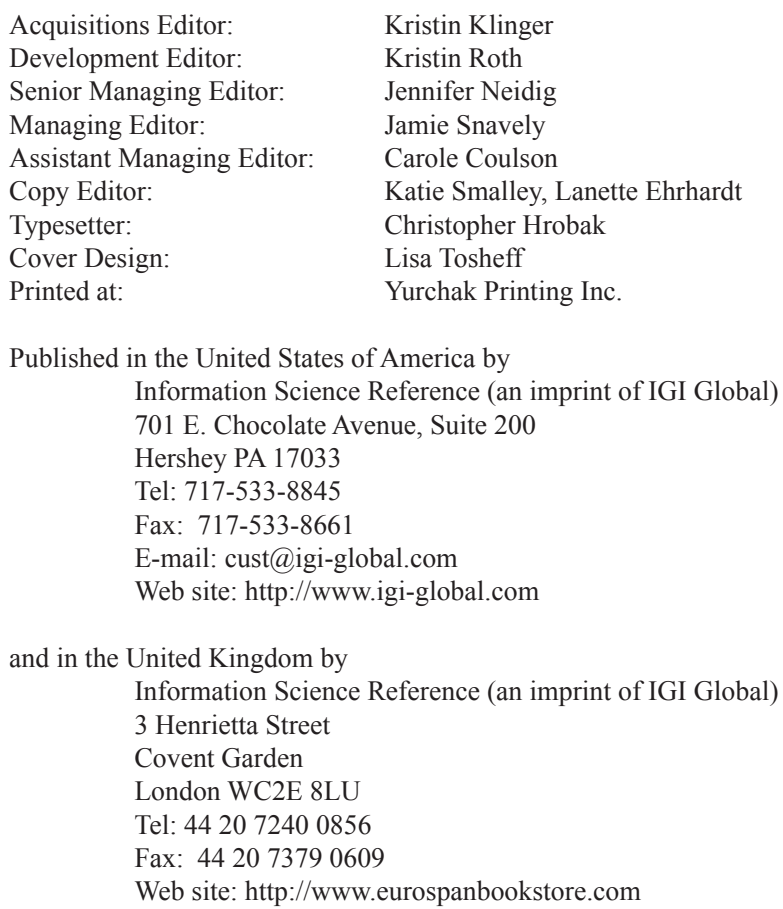

Printed at:

Published in the United States of America by

Information Science Reference (an imprint of IGI Global)

701 E. Chocolate Avenue, Suite 200

Hershey PA 17033

Tel: 717-533-8845

Fax: 717-533-8661

E-mail: cust@igi-global.com

Web site: http://www.igi-global.com

and in the United Kingdom by

Information Science Reference (an imprint of IGI Global)

3 Henrietta Street

Covent Garden

London WC2E 8LU

Tel: 442072400856

Fax: 442073790609

Web site: http://www.eurospanbookstore.com

Copyright (C) 2008 by IGI Global. All rights reserved. No part of this publication may be reproduced, stored or distributed in any form or by any means, electronic or mechanical, including photocopying, without written permission from the publisher.

Product or company names used in this set are for identification purposes only. Inclusion of the names of the products or companies does not indicate a claim of ownership by IGI Global of the trademark or registered trademark.

Library of Congress Cataloging-in-Publication Data

Handbook of research on computer mediated communication / Sigrid Kelsey and Kirk St. Amant, editors.

p. cm.

Summary: "This book provides academics and practitioners with an authoritative collection of research on the implications and social effects computers have had on communication. With 65 chapters of innovative research compiled in this comprehensive reference source, this handbook of research is a must-have addition to every library collection"--Provided by publisher.

ISBN 978-1-59904-863-5 (hbk.) -- ISBN 978-1-59904-864-2 (e-book)

1. Computer-assisted instruction. 2. Communication and technology. 3. Information technology--Social aspects. I. Kelsey, Sigrid. II. St. Amant, Kirk, 1970-

LB1028.5.H31632008

378.1'734--dc22

2008001871

British Cataloguing in Publication Data

A Cataloguing in Publication record for this book is available from the British Library.

All work contributed to this book set is original material. The views expressed in this book are those of the authors, but not necessarily of the publisher. 


\title{
Chapter L \\ The Use of CMC Technologies in Academic Libraries
}

\author{
Courtney D. Crummett \\ National Library of Medicine, National Institutes of Health, USA
}

Anna H. Perrault

University of South Florida, USA

\begin{abstract}
Computer mediated communication technologies such as instant messaging, blogs, wikis, and podcasts provide new avenues to foster communication and collaboration in the academic library environment. These tools provide innovative ways to reach new technologically savvy academic library users, highlight library services, and allow the library to remain the intellectual center of the academic community. Additionally, these tools also provide mechanisms for internal staff development and collaboration, saving time and building a more technologically expert staff. This chapter highlights various ways that the academic library community can incorporate CMC technologies by providing current examples of instant messaging, blog, wiki, and podcast implementation.
\end{abstract}

\section{INTRODUCTION}

The field of computer mediated communication (CMC) investigates the process of human communication through computer technology by examining the expression of self, the development of relationships, and the establishment of communities (Thurlow, Lengel, \& Tomic, 2004). Computer software, applications, and networks aid in fostering human communication by diminishing geographical barriers and narrowing the digital divide for users.
Many CMC tools incorporate and implement activities long associated with libraries and librarians: collecting, categorizing and disseminating information. It is only natural that libraries incorporate new $\mathrm{CMC}$ technologies to reinforce fundamental information resource management and retrieval practices.

The purpose of this chapter is to discuss specific CMC tools and their applications in the academic library environment for facilitation of communication and improved access to information. CMC tools to be discussed include: instant 
messaging, blogs, wikis, and podcasts. The chapter presents the viewpoint that academic libraries must employ CMC technology tools to meet the needs of their staff and users. The utilization of each tool and the different uses internally, among academic library staff, and externally, for library users will be explored. Issues such as security, training, and maintenance will be discussed in addition to their benefits and disadvantages. Specific libraries incorporating these tools and their experiences will be presented. Characteristics and behaviors of the new academic library user will be discussed. Current trends and future predictions of how academic libraries will implement CMC tools will also be discussed.

\section{BACKGROUND}

Advances in technology are creating a dynamic environment for the academic library which is considered the last bastion of organized and authoritative information. Within the academic setting, the library has always been a focal point for faculty, researchers, and students, but changes in technology and its effects on society are diminishing the library's role as an academic focal point. The ubiquitous presence of the Internet and our society's reliance on technology are changing information seeking behaviors of academic library users. Students are less frequently entering the library. Instead, they are turning to alternative information sources. Faculty are conducting their own research and decreasing their dependence on the library. An increase in distance education curricula has reinforced geographic barriers between new students and the library. Academic library circulation service began to decline in 1996 and in 1998 reference transactions began to fall. In 2000, both reference and circulation statistics dropped below numbers observed in 1991 (Kyrillidou \& Young, 2004). Traditional brick and mortar institutions are transitioning into the digital sphere by incorporating technol- ogy and electronic applications to reach users and facilitate staff development.

Some of the top issues facing academic libraries include the education of librarians, maintaining a role in the academic environment, and supporting the new academic library user (Hisle, 2002). Updating the skills and knowledge of current librarians is a challenge that many library administrators now face. Information retrieval practices are evolving with the increased use of digital informational resources. Increases in the availability of electronic resources require librarians to rethink traditional information delivery techniques. Further, library staff communication practices must remain consistent with those of the academic community and users. While the intellectual community turns to the Internet for information, the academic library must attempt to remain the focal point by offering services that support and coincide with the electronic environment. Compared to 5 years ago, modern academic library users have different demands, different information seeking behaviors, and different expectations of accessibility. Most users have a dependence on Google-type search engines for information retrieval resources and find traditional library Web pages and databases unattractive (Lippincott, 2005). Current users are surrounded by technology and depend on the digital sphere for information.

The current generation of college student and academic library users had access to computers growing up and never experienced life without cell phones. This generation, referred to as the Net Generation, the Digital Generation, or Millennials (Gardener \& Eng, 2005), has experienced their education outside of traditional libraries. This generation embraces technology, feels it is part of daily life, making learning and teaching more effective, and facilitating social connections. In general, they prefer group work, wish to achieve academic success, and have developed a unique learning style focused on multimedia delivery and self-education (Oblinger \& Oblinger, 2005). 
Research reports that current academic library users have distinct attributes which include the possession of great expectations, the expectation of customization, experienced use of technology, and the ability to use new communication modes (Gardner \& Eng, 2005). These attributes, coupled with their ubiquitous use of collaboration technologies, are similar to practices of Library 2.0, the new loosely defined movement within academic libraries, which encourages libraries to become more interactive, collaborative, and modernize the way services are delivered to users. Library 2.0 is derived from the model of Web 2.0, which refers to a new improved generation of the Internet focused on interaction, collaboration, and sharing.

Principles of Library 2.0 set forth by Chad and Miller (2005) include: (1) The library is everywhere; (2) The library has no barriers; (3) The library invites participation; (4) The library uses best-of-breed systems. The concept of Library 2.0 emphasizes a user-centered library where services and resources are geared toward the users' information seeking behaviors. The model of Library 2.0 has created controversy in the cyberworld, with some professionals claiming that these ideas are not new to librarianship, while other professionals and institutions are taking these principles and expanding the topic with conferences, workshops, and blogs dedicated to educating the field on how to implement Library 2.0 practices in libraries.

Libraries have been slow adopters of these technologies while library users have been fast adopters. If academic libraries want to maintain relevance, they must make their best attempt to meet the user on level playing fields filled with technology, fast accessibility and no obstacles to information and resources. Ramsay and Kinnie (2006) state that, "instead of pulling people in, librarians need to reach outward to become an integral part of the routine interactions of faculty and students" (p. 34). Libraries following the Library 2.0 principles, like the majority of the rest of the world, have taken advantage of the Internet and the Web to reach the masses, keep up with technology, and retain relevancy. It seems only natural that these institutions should continue to use new technologies that depend upon Internet and Web connectivity for communicating with staff and library users. An exploration into the ways academic libraries are incorporating the trend of using technology for people to people connections and information resources provides a bridge between the academic library setting and the field of CMC.

CMC technologies such as instant messaging, blogs, wikis, and podcasts connect library services, library users, and library staff in a progressive manner echoing many concepts of the Library 2.0 movement.

\section{MAIN FOCUS}

With the increasing abundance of technologically savvy college students, academic libraries have the responsibility to utilize new tools to reach their users. Further, techniques used by students to gain access to information are changing. Students are less frequently coming into the physical library to seek information services and resources and are depending more on the electronic version of their university or college library (home page) for sources. A recent survey reported that $73 \%$ of college students say they use the Internet more than the library (Jones, 2002). CMC tools such as instant messaging, blogs, and podcasts provide solutions to information access barriers observed in the academic library.

CMC tools used among library staff encourage faster workflow, easier communication, and effective management. As the organizational structure of the academic library changes, internal communication among staff and between departments becomes difficult. No longer are e-mails and Web pages sufficient for communication and collaboration between library staff. Blogs offer 
instant documentation platforms without physical limitations. Wikis are designated as common spaces for departmental projects, eliminating lost e-mails with numerous editions of working documents attached. Additionally, CMC tools also offer ways for staff to keep current in technology practices.

Academic libraries must meet the needs of their staff and users. CMC tools have internal and external uses within the realm of academic libraries. These tools provide communication, sharing, and management mechanisms.

The following sections provide examples of the use of CMC technologies in academic libraries, such as instant messaging, blogs, wikis, and podcasts in various internal and external mechanisms. Internal mechanisms include communication and collaboration among library staff, while external mechanisms include communication between the library and the user. This chapter does not attempt to provide a complete list of all academic libraries using $\mathrm{CMC}$ technologies. The examples given were taken from a literature review of the library and information science scholarly literature and from online directories such as Library Success: A Best Practices Wiki, LISWIKI, and Libdex as of December 2006.

\section{Instant Messaging}

Instant messaging, referred to as IM, is a more traditional CMC technology; it has been available almost as long as electronic mailing. More than 53 million Americans have used IM and of those, $12 \%$ use IM on a daily basis (Shiu, 2004). IM offers immediate gratification by providing real time, instantaneous communication between two or more people. IM chat rooms can be private or public, while photos, documents, and other files can be transferred via IM.

IM has been implemented in academic libraries for both external and internal use. Most commonly, IM has been used to improve and supply reference services of the library to a greater number of users than the traditional reference desk allows. IM reference diminishes geographical barriers often observed by distance users. Additionally, IM offers an anonymous vehicle for information retrieval helping to alleviate common psychological barriers such as intimidation and embarrassment that many library users face when approaching the physical reference desk. IM reference meets the needs of fast paced users already employing IM technologies for personal use. Younger Internet users are employing IM more often then other age groups; $62 \%$ of IM users are between the ages of 18 and 27 (Shiu, 2004).

Internal use of IM within the workforce is becoming a standard. A quarter of daily Internet users $\log$ into IM at work and $40 \%$ of those who IM at work feel that it improves teamwork (Shiu, 2004). IM used internally provides efficient communication among staff. Internal chat at the reference desk can be used to ask for assistance when answering questions. Further, internal IM can be used to announce staff member availability for answering subject specialty questions, as reminders for scheduled meetings, or for staff file sharing.

Due to the seniority of instant messaging, there has been much scholarly literature written discussing library use, user satisfaction, implementation plans, as well as evaluation techniques of instant messaging applications. Sloan (2004) performed a content analysis review of the Library and Information Science literature and found over 700 citations regarding instant messaging, virtual reference, and digital reference services.

Instant messaging is not intended to replace traditional reference services, but is used as a supplement to an academic library's reference services. Certain common user questions are perfect for IM reference, such as directional or procedural questions. Reference librarians at North Carolina State University (NCSU) use IM to determine how users search in order to offer suggestions on how to improve search strategies. Reference librarians at the University of Tennessee 
find that the IM reference service is sometimes utilized by users within the library because they do not want to give up their computer terminals (Tenopir, 2004). During 2000-2001 the University of Buffalo launched an IM reference service pilot project during which user demographics, comments, and usage data were collected. Evaluation of the IM service showed that young users and users working in computer labs used the IM reference service most, followed by distance education students (Foley, 2002).

Using IM reference in academic libraries provides the opportunity to reach subgroups of the student population. Academic distance learners are an increasingly large group of users who may not receive library assistance through bibliographic instruction or at the point of need within the library (Porter, 2003). Offering IM reference services at an institution with a large distance education enrollment is a method used to bridge the gap between the reference librarian and the distance learner. It has been found that during IM reference sessions a reference interview can be performed adequately, services are satisfactory, and provided in a timely manner (Porter, 2003). Further, IM services can be targeted to specific student populations. Pennsylvania State University librarians reported that when using IM reference services targeted to at-risk learners, as opposed to e-mail or face-to-face, the student's results and pass rates increased (Abram, 2004).

In 2004, an exploration of digital reference service use in academic health science libraries showed that of the 132 libraries investigated, 36 (27\%) used chat reference, an increase from 25 (21\%) libraries reported in a previous exploration by the author in 2002 (Dee, 2005). IM reference matches well with the fast paced needs of academic health science library users such as medical school students, researchers, and health care professionals. Often, these users need information at the point of care. IM reference provides immediate service and its use is increasing within academic health science libraries.
Used internally, IM software provides the advantage of real-time collaboration and communication. Institutions, groups, or departments use IM to clear up minor problems quickly, to have discussions when getting together in one physical location is difficult, and to edit documents (Fichter, 2005). At the University of Saskatchewan, the library staff uses IM internally to notify other staff about when they are available to answer reference questions. Their library is small and the reference desk is not staffed most of the time, so this notification system helps with time management and ensures that users are served (Fichter, 2004).

Simply put, IM technology can help academic librarians to network with other library professionals and colleagues, supply a platform to informally discuss professional issues and problem solve, and gain technology respect from current IM-using library users. IM software is easy to use, can be implemented for free or at low cost, and can be used on any type of electronic device.

\section{Blogs}

Blogs (an abbreviated form of the term "Web log") represent one of the most popular and highly used CMC technology tools currently available. Simply defined, a blog is an online journal consisting of running commentary or topics of importance to the author, usually shown in reverse order with time and date stamps, referred to as posts. In general, a blog can be a diary, a news source, a discussion forum for collaborative projects, or a collection of links. A blog can include opinions, peer reviewed literature, collected authoritative information, reviews, or photos. Although the content and purpose of blogs can vary greatly, the format of easily scannable information stacked top to bottom is consistent, thus making it a comfortable technology.

Blog software is usually free or inexpensive and easy to develop, implement, and maintain. Blogs can be implemented without knowing any 
HTML or other computer language and do not require space on institutional servers. Blogs can be developed by multiple authors where geography may otherwise serve as a restriction and can be coupled with RSS feed applications (Really Simple Syndication) which notify the reader of updates to their favorite blogs. Of online Americans reporting, $25 \%$ of Internet users say they read blogs, while $9 \%$ say they have created blogs. Further, $19 \%$ of online Americans between the ages of 18 and 29 have created blogs (Pew, 2006).

Academic libraries can implement blogs to improve communication with library users and among staff, improve traditional services, promote library service and share library news. Gordon and Stephens (2006) encourage libraries to use blogs due to the benefits of improved communication and practice with technology.

The Eastern Kentucky University (EKU) Library implemented a "Reference Desk Frequently Asked Questions Blog" for the reference librarians. Only available to internal library staff and not accessible by library users, blog entries, authored by the EKU reference librarians, contain useful information about popular questions being asked at the reference desk (Stone, 2003). Using blogs at the reference desk provides a faster and more accurate response for the library user due to the collaborative work of the librarians. Blogs are searchable by date, category, or keyword; therefore, the reference blog can serve as a searchable archive. New librarians find blogs more effective for internal reference support and documentation due to the search and archival capabilities when compared to the more traditional use of e-mail distribution lists or spiral bound notebooks (Barton \& Wesmantel, 2006). Overall, the EKU reference librarians have stated that the reference desk blog has helped them anticipate library user's questions, keep answers to popular questions accessible, and improve the communication between reference staff (Stone, 2003).

Michigan State University used a private staff blog as a reference desk question recording tool to document and organize all questions received at public services desks throughout the entire library system. The information collected was used to assess the effectiveness of the library's reference services and management decisions were made based on information collected from the blog (Barton \& Wesmantel, 2006). Blogs can serve as effective tools to investigate, collect information, and make administrative decisions about resources and services in an academic library.

External blogs can transform the virtual appearance of a library, reaching new library users and sparking new interests. Blogs can focus on a specific information resource such as reference, or subject matter such as science and technology. Additionally, blogs may be used to target a particular audience within the academic community, such as faculty or distance education students, and increase their use of the library.

The Engineering Resources Blog at Drexel University's W. W. Hagerty Library directs users to new engineering resources. New print and electronic resources, research tips for faculty and students, Web resources and library events are showcased via the Engineering Resources Blog. Further, the Engineering Resource Blog pays close attention to RSS feeds and announces when electronic resources, databases, journals, and other resources implement RSS feed tools. These resources use RSS feeds for enhanced services such as saved queries and table of contents listings (Bhatt, 2005). These resource enhancements trickle down to the student, researcher, or faculty member via the Engineering Resources Blog.

NCSU Libraries used an external blog to replace the Natural Resources Library's HTML based news page and monthly newsletter. Differing from more traditional blogs, the reply/comments feature was disabled because the blog was intended as a publishing medium only. Staff at the Natural Resources Library found the blog software easier to use and valued being able to access the blog from work or home. With the obvious success of the Natural Resources Library 
blog, the main library of NCSU started a news blog on the library's homepage (Chang, 2004). McMaster University provides library news to users in blog form, separated by topics such as "all library news," "e-resources," and "events." Library users at McMaster can personalize their library RSS blog feed, depending on the subjects that most interest them.

The Paul J. Gutman Library at Philadelphia University has taken blogs one step further to encourage library use. Gutman Library has incorporated a library blog inside of the university's courseware used by a majority of the student and faculty population. Results from a survey conducted to assess the effectiveness of the new placement stated that $75 \%$ of respondents found the library blog useful and liked the accessibility through the courseware. In addition, the Gutman Library blog documented increased library user interaction with $15 \%$ of respondents reporting that they attended a library event as a result of reading the blog (Bell, 2005). Although starting and using a blog is rather straightforward, being creative with a blog will have an impact upon the readership.

Blogs supply a quick and an affordable way to promote a library's special collections or highlight interesting resources. The University of Colorado at Boulder implemented blog software to promote the Government Publications Library (Gerke, 2006). Blog technology is ideal for the subject of government documents because government publications, news, and reports are constantly being released, published or announced. Further, academic library users may be unaware of a library's special collection. The University of British Columbia's UBC Academic Blog-Google Scholar Blog serves as an information resource examining the evolution of academic scholarly searching. Incorporating popular technology, such as a blog, to market a special collection or a popular library issue creates a technology connection between the collection and the user.
Thus, blogs have the capabilities to reduce emails and paper clutter, encourage the sharing of knowledge and experience, in addition to serving as a method to create searchable archives (Gordon $\&$ Stephens, 2006). Externally used, blogs create a new way to reach library users, impart a new pathway to other resources for library users, and provide mechanisms for library-user interaction (Huwe, 2003). When blogs are used internally, both staff development and community building are fostered, contributing positively to the institution.

\section{Wikis}

Wikis are $\mathrm{CMC}$ technologies used to encourage and facilitate communication and collaboration. The word wiki means "quick" in Hawaiian and refers to the software that allows users to easily view, create, and edit Web pages without having to know HTML, JavaScript, ormarkup languages. Wikis originated in the mid-1990s and have become recently popular due to the frequently used Wikipedia, an encyclopedia created by the online community. As of December 2006, Wikipedia is available in over 100 languages, and the English version of Wikipedia is said to be the largest wiki in the world, with over 1,517,658 articles ("Statistics," 2006).

The most important idea behind wikis is that the community of users act as quality controllers who keep content accurate and appropriate (Guenther, 2005). Wikis can be completely open with unlimited access, lockable with specific page restrictions, restricted to registered members or specific IP addresses, or any combination of those (Chawner \& Lewis, 2006). Wiki software archives content, additions, and changes made with "history" or "recent changes" pages.

Within the academic library environment, wikis are technologically improved versions of many traditional activities such as group development and sharing, information resource building, and knowledge management. With the widespread 
popularity of Wikipedia, wikis offer a great way to catch the attention of the wiki-wise library user, while traditional library resources and services are improved by the collaborative development. Wikis can be used in libraries for subject guides, as community information resources, and internal document development platforms. Using wikis to build subject guides adds currency to the resource and dissolves geographical barriers with concern to editing the subject guide. Wikis can serve as effective tools for library managers to disseminate and organize institutional procedures and process documents. Library staff can use wikis to brainstorm, manage, and edit documents, instead of e-mailing back and forth different and confusing versions of the same document (Cochenour, 2006). In addition, some have suggested that wikis would be a great way to make the library's online catalog more like Amazon with book synopses, cover art, and wish lists (Farkas, 2005).

A Reference and Instruction Librarian at Ohio University's Alden Library uses wiki software to supply online research guides in the subjects of general business, international business, and marketing for students and faculty in one central wiki, called The Biz Wiki. The wiki is organized by category, includes a variety of business research tools, and research "how to" guides (Boeninger, 2005).

Frumkin (2005) suggests libraries implement wikis as finding aides, developed and supported by library staff, yet with open access for users to comment and edit, thus becoming a current and dynamic annotation tool to benefit all users. Academic librarians at Butler University have implemented the WikiRef, a collaborative review of databases, books, and Web sites within the Bulter University Libraries reference collection. University librarians, faculty, staff, and students are encouraged to participate in building the content on the WikiRef, making it a truly collaborative reference resource. Librarians hope comments and participation on WikiRef will elucidate the user perspectives and opinions of the library resources (Ginsberg, 2006).

Wikis have also found their way into academic library bibliographic instruction classes. Using wikis for library instruction is a great way to meet the technology needs of the students. Most college students are familiar with wikis and the implementation of wiki platforms within the traditional library instruction curriculum provides a librarian with credibility and approval from the perspective of the tech-savvy college student, while promoting the use of new technologies in the library. Additionally, using wiki software for library instruction provides another means for library staff to learn new technologies.

The University of British ColumbiaBiomedical Branch Library currently hosts the HealthLibWiki: A Knowledge Base for Health Librarians. This wiki serves to provide an international perspective on health science librarianship, while still emphasizing issues affecting practices in Canada such as expert searching to support the development of systematic reviews in medicine, searching for grey literature, and evidence-based medicine.

At Miami University Libraries, the information desk staff uses an internal wiki to share and update information needed to perform duties. The staff at the information desk, which is located in the largest of the four campus libraries, answer directional and basic information questions and refer library users to other services. The information desk is staffed by a diverse group of employees who work nearly day and night in numerous shifts, answering over 10,000 questions a year. This dynamic work atmosphere impedes communication. Building a staff wiki has solved information desk communication problems by providing a platform to discuss popular questions, resources, and policies. The information desk wiki contains reference interview techniques, facilities, services and hours, renovation updates, and staff polices (Withers, 2005). With time and physical location serving as an obstacle in the 
way of an effective and collaborative information desk, Miami University Libraries have utilized the convenience of wiki technology.

Similarly, Oregon State University Libraries use an internal wiki for staff to discuss the library's reference knowledge management software, the Reference Desk Manager. Wiki technology is also used at Oregon State University Libraries as a staff knowledge management tool to encourage internal communication and information management for internal staff projects (Frumkin, 2005).

Function and application first attracted the academic librarian to the wiki, but as wikis have evolved, the application of wikis within the academic library is expanding. Both internal and external wikis have been implemented at NCSU Libraries. An internal wiki was created in 2003 as the "intranet" used by library staff for document, list, and report development. Wikis are replacing library home pages due to the fast editing feasibility and unlimited geographical access. In 2004, the NCSU moved their library homepage to a wiki platform due to the attractive applications such as file-uploading, version-history reports, and a simpler editor (Chang, 2004). Similar uses have been implemented by the Aiken Gregg-Graniteville Library of the University of South Carolina. The Aiken Library uses wiki software to host the library home page and intranet. Library procedure manuals, strategic planning and assessment documents, and professional development resources are all found on the Aiken Library's wiki intranet (Chawner \& Lewis, 2006).

By far, the wiki is currently the trendiest CMC technology used in academic libraries. Overall, collaboration and communication seem to be the greatest benefits of wikis. With the ease of use and immediacy of a wiki, library staff committees and groups become more efficient. In summary, Farkas (2005) states "at their least, they are spaces for quick and easy collaborative work. At their best, they can become true community resources that can position the library as an online hub of their local community" (para. 3) facilitating com- munication among the library and student body using computer mediation.

\section{Podcasts}

The newest CMC technology used by academic libraries to share information and communicate with users is podcasting. Podcasts are digital recordings of various content available on the Internet for anyone to download for listening on to their computer or MP3 player. Over 22 million Americans own personal MP3 players, while 6 million of those Americans have downloaded a podcast (Rainie, 2005a). Once recorded, podcasts are registered on a podcast directory on the Internet. Podcasts are becoming ubiquitously available because of RRS syndication, just like blogs. Podcasts can be created by anyone with a computer, sound card, audio recording software, a microphone, server space, and Internet connection.

Podcasting allows libraries to supply traditional services with a new technological twist. The ability to incorporate portable video and sound can enhance many services and resources found in the library. Rich dynamic media incorporated into traditional library services coupled with portability present an environment familiar to the technologically savvy college student. Users can download and listen at their own convenience without geographical limitations. Podcasting is both simple for the creator and user, making the technology a perfect fit for academic libraries.

Podcasts increase the visibility of library events and activities, therefore building the library community and connecting more users to the library. The use of podcasting in academic libraries increases communication with faculty wishing to incorporate podcasts into their coursework. Librarians assist faculty with podcasting creation and the library serves as a repository for students to access. Further, the adoption of podcasting technology facilitates the professional development of the library staff by the exposure to new software and inspiring creativity. 
One of the most common ways academic libraries currently incorporate podcasts into library services is by turning the traditional library tour into a podcast, similar to museum virtual tours. Western Kentucky improved the traditional library tour by hosting a tour via a podcast downloaded from the Library's homepage (Lee, 2006). Purdue offers virtual library tours as podcasts as well (Shaughnessy, 2005). The George C. Gordon Library at Worcester Polytechnic Institute offers library tour podcasts and supplies MP3 players for users. The library tour podcast details the layout of the library building and highlights resources and services. Audio tour signs are placed around the library to signify highlighted items on the podcasts.

Lee(2006) suggests enhancing the library tour podcasts by directing the material and style to a particular audience, such as creating a podcast library tour designed to guide freshman students through the process of conducting research for their first composition paper or developing a podcast to welcome new faculty.

American University, Washington College of Law Library uses podcasts to promote library activities and events in addition to mechanisms for supplying alternative formats of classroom lectures. From September to December of 2005, there were 4,917 regular subscribers and 33,742 MP3 downloads. Librarians stated that podcasts have made content available to American University community members, as well as providing an alternative tool for non-English speaking students (Balleste, Rosenberg, \& Smith-Butler, 2006).

Johns Hopkins University's Sheridan Library uses podcasts to enhance library instruction services with database tutorials and bibliographic citation instructions (Lee, 2006). Users can hear audio demos of new databases offered and specific examples of how faculty and students can benefit from using resources. St. Johns's University Library created podcasts for library instruction lectures, a library tour, and recordings of guest speakers (Shaughnessy, 2005).
In the fall of 2005, the George C. Gordon Library at Worcester Polytechnic Institute implemented a new service program, Audio to Go Podcasts. The program incorporated podcasting technology to provide students with the latest news, events, and information about library resources. Arizona State University Libraries offers podcasts through the library's news blog, The Library Channel. Users can find information about resources and special exhibits occurring at the library through podcasts.

Podcasts can also be the vehicle for a particular service offered by the library. The Nova Southeastern University Law Library and Technology Center converted the Legal Replays service from traditional Internet streaming audio to podcasting. Legal Replays is a repository of audio-recorded law lectures given by law faculty. With Legal Replays in the form of podcasts, students automatically receive new content via RSS feed technology, can download podcasts to iPods or mp3 players, and can take the podcasts wherever they go and listen at their own convenience (Balleste, Rosenberg, \& Smith-Butler, 2006).

Podcasts are an innovative way for academic libraries to announce library news, disseminate lectures and course materials, highlight special collections, improve traditional library instruction curriculum, and encourage the technological growth of the library.

\section{Barriers and Disadvantages of CMC Technologies in Academic Libraries}

Although CMC technologies are making their mark in academic libraries, there are disadvantages and reservations about implementing IM, blog, wiki, and podcast technologies. Foremost, security is a continuous issue within the academic library community. The security of library user and personnel information, the fear of increased spam, and the possibility of unauthorized use are common barriers to the implementation of new technologies in any organization. Fortunately, 
most CMC technologies can be implemented behind institutional firewalls to avoid unauthorized access and use. Password protected blogs and wikis enable secure collaborative workspaces. Firewalls and other security measures help to make these applications more reliable within the academic library setting.

The fear of technology is often a barrier to implementing exciting technologies. Convincing library staff to use new technology tools or change a service is sometimes difficult. Further, implementing $\mathrm{CMC}$ technology requires staff time and dedication. It is difficult to redirect staff time to new projects and services when staff are already busy enough. Additionally, the value of services and resources revamped with CMC technologies such as wikis or blogs is directly related to how much attention is given to the technologies. Without maintenance of these tools the currency, effectiveness, and use will decrease, thus rendering the resource less valuable.

Sometimes implementing a new technology is not appropriate depending on the needs of the community and the resources of the library. Why build it if no one will come? Although research highlights the technological aptness of the new academic library user, it is not safe to generalize that all academic library users are technophiles. Further, the benefits of implementing any of these technologies would be negated if it resulted in the exclusivity of a user group. Older students may not be as comfortable with technology as collegeage library users. Alienating a library user via the use of technology is a possible disadvantage of $\mathrm{CMC}$ tools implementation in libraries. A proper assessment of an academic library's culture and organizational structure will aide in determining if $\mathrm{CMC}$ technologies are appropriate to introduce to a community.

The lack of a standard for many of the CMC technologies discussed here fosters trepidation among those responsible for implementation. For example, the lack of a standard for wiki content markup language, which would encourage data migration and interoperability between the various wiki engines, is perceived as a disadvantage of wiki technology (Chawner \& Lewis, 2006). Additionally, the unknown level of sustainability of software, especially those that are currently available for no fee, initiates a cautious attitude among academic librarians. Staff time and energy used to develop these technologies is wasted if the software used disappears or changes drastically.

It can be argued that using a computer or some other digital device to communicate removes the human element and creates barriers to effective communication. This may be true in some instances, but a further investigation of preferences and common behaviors of specific user groups will help to determine if barriers are formed by implementing $\mathrm{CMC}$ technologies. Currently, there is a lack of qualitative and quantitative research investigating the impact of and user perception related to the use of CMC technologies in academic libraries. It is imperative that evaluations of these tools are conducted and published in the scholarly literature. Although the majority of academic library users fall on the digital side of the digital divide and benefit from digital resources and services such as subject-based wikis and IM reference, a better understanding of how users perceive and react to these CMC technologies would benefit the academic library community.

Lastly, the use and effectiveness of CMC technology and the facilitation of communication and collaboration are dependent on the marketing of the products as well as the reason for implementation. If library news blogs and subject guide wikis are not promoted, they may not be found and used. Users can't find services that aren't advertised, whether they are new technologies or traditional library resources. And, using new technologies, such as podcasting, just because they are "cool" or the latest new thing, without a specific purpose in mind, is not an effective use of time or resources. 


\section{FUTURE TRENDS}

$\mathrm{CMC}$ technologies and their place in academic libraries do not stop with IM, blogs, wikis, or podcasts. Many other applications are being used and undoubtedly there will be new applications developed in the future.

It has been suggested that the library online public access catalog (OPAC) will be the next big library service to be impacted by changes in technology. Incorporating Amazon-style "other people who bought this also bought..." and Netflix-styled "recommended for you" suggestion lists and an organized movie queue within an academic library's OPAC creates a more user centered and searchable information resource (Mathews, 2006).

Library users are becoming increasingly dependent on mobile technology. Will library users be able to download OPACs onto their cell phones? Additionally, library users want consistency within their technology. Will misspelled search queries yield a Google-like "did you mean...?" Second Life, the online virtual reality world, where users create avatars to interact, communicate and simulate real life, has recently gained international popularity. Could students create a virtual librarian customized to their exact information needs? It is impossible to predict what new technology tools will be incorporated into an academic library; the options are endless as technology will continue to develop new applications.

\section{CONCLUSION}

At first, one might think that the academic library is the most unconventional place for applications such as blogs, wikis, or podcasts. This chapter has provided examples of ways these technologies are already being used in innovative academic libraries. Academic libraries are employing the CMC technologies to progress organizationally, providing better communication and staff col- laboration. These technologies also offer academic libraries alternative media to reach more library users. With constant advances in technology, the institution of the academic library must try to stay a step ahead of library users, as well as continue to serve as a resource for those not so technologically savvy.

One of the biggest advantages of the technologies discussed in this chapter is that they are available free to the academic library and free to the user. Costs arise only in the hardware used to implement the software, to which most academic libraries and library users already have access. Of course, advertisements and security issues may be undisclosed within this free cost. With all the budget concerns in higher education, free software is a good and nearly cost-free way to improve the academic library.

What happens next in the world of academic libraries and $\mathrm{CMC}$ technologies should include a larger amount of research conducting assessments of the user perspective of CMC technologies in academic libraries. Without feedback from the user and proper evaluation, the full capabilities of these technologies may not be within reach of the academic library community. Thus far, the use of these technologies in academic libraries has brought valuable benefits, internally and externally.

\section{REFERENCES}

Abram, S. (2004). Twenty reasons to love IM. Information Outlook, 8(10), 40-42.

Balleste, R., Rosenberg, J., \& Smith-Butler, L. (2006). Podcasting, vodcasting, and law libraries. American Association of LawLibraries Spectrum, 10(8), 8-10.

Barton, E., \& Wesmantel, A. (2006). Reflogs now. Library Journal, 131(16), 28-30. 
Bell, S. (2005). Where the readers are. Library Journal Net Connect, 8 .

Bhatt, J. (2005). Blogging as a tool: Innovative approaches to information access. Library $\mathrm{Hi}$ Tech News, 9, 28-32.

Boeninger, C. (2005). A wiki as a research guide. Library Voice. Retrieved February 16, 2008, from http://libraryvoice.com/archives/2005/07/13/awiki-as-a-research-guide/

Chad, K., \& Miller, P. (2005). Do libraries matter? The rise of Library 2.0. United Kingdom: Talis. Retrieved February 16, 2008, from http://www. talis.com/downloads/white_papers/DoLibrariesMatter.pdf

Chang, M. (2004). I've gathered a basket of communication and collaboration tools. Computers in Libraries, 24(8), 6-11.

Chawner, B., \& Lewis, P. (2006). WikiWikiWebs: New ways to communicate in a Web environment. Information Technology in Libraries, 25(1), 33-43.

Cochenour, D. (2006). Is there a wiki in your (library) future? Colorado Libraries, 32(1), 34-36.

Dee, C. (2005). Digital reference service: Trends in academic health science librarians. Medical Reference Services Quarterly, 24(1), 19-27.

Farkas, M. (2005). Using wikis to create online communities. WebJunction. Retrieved February 16, 2008, from http://webjunction.org/do/Printer FriendlyContent?id=11264

Fichter, D. (2004). Technology trends for intranet librarians. Online, 28(6), 45-48.

Fichter, D. (2005). The many forms of e-collaboration: Blogs, wikis, portals, groupware, discussion boards, and instant messaging. Online, 29(4), 48-50.

Foley, M. (2002). Instant messaging reference in an academic library: A case study. College \& Research Libraries, 63(1), 36-45.
Frumkin, J. (2005). The wiki and the digital library. OCLC Systems \& Services: International Digital Library Perspectives, 21(1), 18-22.

Gardner, S., \& Eng, S. (2005). What students want: Generation $\mathrm{Y}$ and the changing function of the academic library, Portal: Libraries and the Academy, 5(3), 405-420.

Gerke, J. (2006). Promoting unique collections with a blog. Colorado Libraries, 32(3), 5-7.

Ginsberg, D. (2006). A Wiki wiki (quick) introduction to the wide world of wikis. American Association of Law Libraries Spectrum, 10(9), 8-10.

Gordon, R.S., \& Stephens, M. (2006). Tech tips for every librarian. Computers in Libraries, 26(2), 50-57.

Guenther, K. (2005). Socializing your Web site with wikis, twikis, and blogs. Online, 29(6), 51-53.

Hisle, W. L. (2002). Top issues facing academic libraries: A report of the Focus on the Future Task Force, College \& Research Libraries News, 63(10).

Huwe, T. (2003). Born to blog. Computers in Libraries, 23(10), 44-45.

Jones, S. (2002). The Internet goes to college: How students are living in the future with today's technology. Pew Internet \& American Life Project. Retrieved February 16, 2008, from http://www. pewinternet.org/report_display.asp?r=71

Kyrillidou, M., \& Young, M. (2004). Research librarytrends 2004-2005. Association of Research Libraries, Washington, D.C. Retrieved February 16, 2008, from http://www.arl.org/stats/arlstat/ 05pub/05intro.html

Lee, D. (2006). IPod, you-pod, we-pod: Podcasting and marketing library services. Library Administration \& Management, 20(4), 206-208. 
LibDex. (2006). Retrieved February 16, 2008, from http://www.libdex.com/

Library Success: A best practices wiki. (2006). Retrieved February 16, 2008, from http://www. libsuccess.org/index.php?title=Main_Page

Lippincott, J. (2005). Net generation students and libraries. In D. Oblinger \& J. Oblinger (Eds.). (2005), Educating the net generation. Boulder, CO: EDUCAUSE. Retrieved February 16, 2008, from http://www.educause.edu/books/educatingthenetgen/5989

LIS Wiki. (2006). Retrieved on February 16, 2008, from http://liswiki.com/wiki/Main_Page

Mathews, B. (2006, May 10). Week 3 from Brian Mathews on Academic Library 2.0. In ALA Library 2.0 Podcast. Retrieved February 16, 2008, from http://podcasts.alablog.org/blog/_trackback/1948388

Oblinger, D., \& Oblinger, J. (2005). Is it age or IT: First steps toward understanding the net generation. In D. Oblinger \& J. Oblinger (Eds.). (2005), Educating the net generation. Boulder, CO: EDUCAUSE. Retrieved February 16, 2008, from http://www.educause.edu/books/educatingthenetgen/5989

Pew Internet and American Life Project. (2006). New data on blogs and blogging. Retrieved February 16, 2008, from http://www.pewinternet. org/press_release.asp? $\mathrm{r}=104$

Porter, S. (2003). Chat: From the desk of a subject librarian [At La Trobe University]. Reference Services Review, 31(1), 57-67.

Rainie, L. (2005a). Podcasting. Pew Internet \& American Life Project. Retrieved February 16, 2008, from http://www.pewinternet.org/pdfs/ PIP_podcasting2005.pdf

Ramsay, K., \& Kinnie, J. (2006). The embedded librarian. Library Journal, 131(6), 34-35.
Shaughnessy, K. (2005). The Libraries Launch Academic Podcasting at St. John's. Retrieved February 16, 2008, from http://www.stjohns. edu/academics/libraries/podcast.sju

Shiu, E. (2004). How Americans use instant messaging. Pew Internet \& American Life Project. Retrieved February 16, 2008, from http://www. pewinternet.org/pdfs/PIP_Instantmessage_Report.pdf

Sloan, B. (2004). Digital reference services bibliography. Retrieved February 16, 2008, from http://people.lis.uiuc.edu/ b-sloan/digiref.html

Statistics. (2006). In Wikipedia, the Free Encyclopedia. Retrieved February 16, 2008, from http://en.wikipedia.org/wiki/Special:Statistics

Stone, S. (2003). The library blog: A new communication tool. Kentucky Libraries, 67(4), 14-15.

Tenopir, C. (2004). Chat's positive side. Library Journal, 129(20), 42.

Thurlow, C., Lengel, L., \& Tomic, A. (2004). Computer mediated communication: Social interaction and the Internet. London: Sage.

Withers, R. (2005). Something wiki this way comes. College \& Research Libraries News, 66(11), 775-777.

\section{KEY TERMS}

Academic Librarian: A working library professional holding a Masters in Library Science or international equivalent.

Academic Library: A designated place, physical or digital, set aside to house scholarly research materials and materials supporting the academic, university, or college community and curriculum. 
Academic Library User: Individuals having access to academic, university, or college library services and resources.

Blog: An online resource composed of varied content in short formatted entries with time and data stamp listing in reserve chronological order, made publicly or privately available.

Instant Message: The transmission from a sender of an electronic message over a computer network using software that instantaneously displays the message in a chat window on the screen of the recipient. Also referred to as chat or IM
Podcast: A Web-based audio recording made available via RSS feed and subscription. Name derived from the combination of iPod + broadcast.

RSS: (Really Simple Syndication or Rich Site Summary) Web-based technology used by Internet users to distribute and retrieve real-time content such as blogs and podcasts, similar to a subscription.

Wiki: A collaborative Web site enabling group sharing by provided mechanisms for content to be edited by users. 